\title{
Recent findings regarding non-native or poorly known diatom taxa in north-western Italian rivers
}

\author{
Elisa FALASCO, ${ }^{*}$ Francesca BONA \\ Department of Life Sciences and Systems Biology, University of Torino, via Accademia Albertina 13, 10123 Torino, Italy. \\ *Corresponding author: elisa.falasco@unito.it
}

\begin{abstract}
Diatoms of the major rivers of North-Western Italy were investigated to highlight the presence of species of particular ecological interest but not as yet recorded. The survey area included streams belonging to seven different hydroecoregions (HERs) with a wide range of physical characteristics. Between 2008 and 2010, 200 samples were taken for the study of the diatom community composition, while a larger set of samples was examined to determine the presence or absence of the nuisance diatom species Didymosphenia geminata (Lyngbye) Schmidt. A specific field study was performed in two rivers characterized by persistent blooms of this species to evaluate the effects of its proliferation on the benthic communities. D. geminata was present in almost $20 \%$ of the samples. From a comparison with published data, we can confirm that $\mathrm{D}$. geminata has recently been expanding its ecological range, as it has been found also in mesotrophic lowlands water. In some instances the formation of massive proliferation has been recorded. The calculation of autecological values confirmed its preference for oligotrophic waters with low mineral content and organic loading, although with a wider ecological amplitude than recorded in the first studies on this species. Another four taxa of particular interest were detected: Achnanthidium subhudsonis (Hustedt) Kobayasi (in 15 sites), Cymbella tropica Krammer (11 sites), Mayamaea cahabaensis Morales and Manoylov (2 sites) and Reimeria uniseriata Sala, Guerrero and Ferrario (18 sites). The first three species must be considered new records for Northern Italy. A. subhudsonis and C. tropica reached up to $20 \%$ relative abundance. From the analysis of their distribution and autecological values, we can assert that $\mathrm{A}$. subhudsonis and $\mathrm{M}$. cahabaensis show a preference for high values of nitrogen, this latter preferring also quite high values of total phosphorus. C. tropica prefers intermediate values of nitrogen nutrients and $\mathrm{R}$. uniseriata is the least demanding species in terms of water quality. All the taxa studied have a wide ecological range, confirming their potential invasive behaviour. Finally, considerations are provided with respect to Italian and European historical data in order to understand whether these species can be considered non-indigenous and/or bloom forming, in the study area. The results may help improve the process of ecological classification of water bodies in the seven HERs, and the water protection actions introduced by the Water Framework Directive (2000/60).
\end{abstract}

Key words: diatoms, NW Italy, Didymosphenia geminata, non-indigenous taxa, river ecosystem.

Received: April 2012. Accepted: June 2012.

\section{INTRODUCTION}

Over the last 40 years, a considerable amount of ecological research has been devoted to biological invasions and their effects on ecosystems. Non-indigenous species (NIS) are considered one of the major menaces to ecosystem integrity worldwide (Mack et al., 2000).

The biogeographical distribution of freshwater diatoms is still a controversial issue. According to Finlay et al. (2002), most diatom species are cosmopolitan, and species that are locally rare or abundant are like that worldwide. According to this hypothesis, it is inappropriate to assert the presence of endemic or exotic diatom species, since many of them have likely been underestimated, and would show a wider geographical distribution with further sampling efforts. On the other hand, several studies support the idea that diatoms have a biogeographical distribution (Vanormelingen et al., 2007; Vyverman et al., 2007). Telford et al. (2006) demonstrated that the dispersal of diatoms was limited, and timescales of isola- tion allowed for regional genetic differences to develop and endemic taxa to evolve. Kilroy et al. (2007) supported this idea by defining endemic and exotic taxa and relating them to different disturbance levels. In the Palaearctic region, the only comprehensive study focussing on invasive diatom taxa considered historical data recorded in France (Coste and Ector, 2000). The authors defined exotic diatoms as taxa not yet found in France until 1990 but showing an important proliferation and rapid dispersal since that time.

Because of its bloom forming nature, Didymosphenia geminata (Lyngbye) Schmidt is by far the most studied non-indigenous diatom worldwide. D. geminata was first collected by Lyngbye in the Faroe Islands and described in 1819 (Lyngbye, 1819). The original distribution range of D. geminata is restricted to northern Europe and North America (in particular the northern hemisphere above the $30^{\circ} \mathrm{N}$ parallel; Blanco and Ector, 2009). In recent years, the presence of this diatom has also been confirmed at 
lower latitudes, as far as New Zealand where it has been considered invasive since 2004. This expansion of the distribution range is probably due to a broadening of the ecological preferences of $D$. geminata. The older literature describes this species as typical of mountain streams with cold waters, fast flows and low nutrient content and conductivity (Patrick and Reimer, 1975; Krammer and LangeBertalot, 1986; Kawecka and Sanecki, 2003; Kilroy et al., 2005). However, recent publications have reported $D$. geminata growing at lower altitude and higher temperatures, albeit never exceeding $20^{\circ} \mathrm{C}$ (Kara and Sahin, 2001; Kawecka and Sanecki, 2003; Rieberger, 1991), and not inhibited by elevated levels of nutrients, such as dissolved reactive phosphorus and nitrates (Kawecka and Sanecki, 2003; Noga, 2003; Subakov-Simiæ and Cvijan, 2004). The high hydrological stability produced by the increasing number of flow regulators, like dams, can be linked to massive proliferation of D. geminata and, as a consequence, with its spread (Kirkwood et al., 2009).

Fossil and recent records of $D$. geminata in Italy are fully presented in Blanco and Ector (2009). Fossil and subfossil records came from Toscana and Lombardia regions (Mandl, 1839; Pritchard, 1842; Griffith and Henfrey, 1883; Corti, 1893), while recent records involve Valle d'Aosta (Brun, 1880), Lombardia (Bonardi, 1888; De Toni and Levi, 1886), Lazio (De Toni and Levi, 1886; Giaj-Levra and Abate, 1994), Trentino (Beltrami et al., 2008a,b,c), and Friuli-Venezia Giulia regions (Zorza and Honsell, 2008). Old records of $D$. geminata in Piemonte region date to the early 1900s and concern Canavese and Verbano districts (Forni, 1925; Forti, 1900; Giaj-Levra, 1927; Monti, 1904). In recent years, biomonitoring programs in the Cuneo and Alessandria districts have highlighted the presence of $D$. geminata in many rivers (Battegazzore, 2008; Battegazzore et al., 2007, 2009, 2010; Maffiotti, personal communication), especially in the Cuneo Province. In the Po river, a massive development of $D$. geminata was found at the Crissolo sampling station (Cuneo, $1380 \mathrm{~m}$ asl), characterized by oligotrophic conditions. Lower abundances were found in downstream stations where nutrient levels were slightly higher. In the Varaita river, D. geminata never exceeded $3 \%$ of the total community abundance (Battegazzore et al., 2007). Huge proliferations and macroscopic blooms have been found in the Erro river since 2007 (Maffiotti personal communication). Also in this case, the water quality was so good that the upper part of the watercourse was proposed as a potential reference site for this type of river. In their most recent paper, Battegazzore et al. (2009) reported a distribution range expansion of $D$. geminata, with high peak abundances in the Corsaglia, Tanaro, and Maira rivers. According to Blanco and Ector (2009), the only record of $D$. geminata in Valle d'Aosta concerns the Courmayeur Valley (Brun, 1880), while there are no literature data on its presence in Liguria region.
The effects of $D$. geminata blooms on river biotic communities are somewhat controversial. There is general agreement on the effects of mats on macroinvertebrates (especially chironomids), i.e. species richness decreases and the community shifts toward tolerant taxa (Blanco and Ector, 2009; Brown, 2008; Larned et al., 2007; Mundie and Crabtree, 1997; Whitton et al., 2009). This is probably due to the microhabitat modifications induced by the thick biofilm and changes in food material availability, mainly consisting of polysaccharide stalks during blooms. On the other hand, the effects of massive proliferations on fish communities are contradictory. Several authors have highlighted the lack of habitat for spawning, feeding or rearing, and diurnal dissolved oxygen fluctuations caused by $D$. geminata blooms as possible threats to fish communities and the fishery industry (Beeson and Mitchum, 2006; Boubée et al., 2008; Cook et al., 2008; Jónsson et al., 2000; Kilroy et al., 2005; Shearer and Erickson, 2006; Shelby, 2006; Stohlgren et al., 2007). In contrast, no effects on salmon or trout populations have been observed in NW England, Norway or Iceland (Jónsson et al., 2008; Lindstrøm and Skulberg, 2007, 2008).

In Italy, the definition of native or exotic species is complicated by the scarcity of historical data. Most of the scientific publications on diatoms of Italian rivers regard data collected over the last ten years, making it difficult to determine whether a taxon is non-indigenous or simply has not yet been recorded or has been misclassified. In this respect, the hydrographic network of North-Western Italy is of particular interest because it includes seven hydroecoregions (HER); therefore, marked differences in climate, geology and relief are found in a relatively small area. During our research, particular attention was given to other taxa of special interest that can be considered potentially non-indigenous according to the following criteria: i) not reported in the European diatom floras up to the beginning of the 1990s; ii) commonly widespread in other continents but not in Europe; iii) known as tropical, subtropical or invasive. We also focused on taxa subject to frequent misidentification (especially in the past). Indeed, apart from isolated reports, no studies have been carried out to establish the distribution of $D$. geminata and of nonindigenous taxa in North-Western Italy based on largescale surveys.

The aims of this study were i) to shed light on the distribution of $D$. geminata in North-Western Italy based on data from regional biomonitoring programs; ii) to analyse the most important effects of macroscopic proliferation of $D$. geminata on benthic communities (both macroinvertebrates and diatoms) at two sampling sites affected by the presence of blooms for most of the year; iii) to highlight the presence of other taxa of ecological interest and newly recorded in the study area.

This study could provide an important contribution to 
the knowledge of the diatom flora of this heterogeneous region, with particular regard to the presence and ecology of nuisance taxa. The findings may be useful for the management of river basins in terms of classification of water bodies and protection of their biotic integrity.

\section{METHODS}

All the surveys were conducted in North-Western Italy (Valle D'Aosta, Piemonte and Liguria regions). Sampling sites corresponded to environmental agency monitoring stations on account of their relevance and data availability.

The study area is highly heterogeneous, including different hydroecoregions (HERs) and rivers with different hydrological regimes, altitudes and impacts. It included the first part (approximately $40 \%$ of the total surface) of the Po river catchment (the largest in Italy) and all the main watercourses belonging to the Ligurian sea basin. Most of the Po river tributaries have a typical nivopluvial regime, with maximum flow in spring and autumn. Some significant watercourses (e.g., Dora Baltea) with glacial feeding were also included. Ligurian rivers have a typical Apennine regime, with maximum flow in spring and autumn and marked summer droughts. The study area includes 7 HERs out of the 21 identified in Italy for implementation of the WFD 2000/60. The Valle d'Aosta region includes one HER, the Inner Alps (HER1), represented by mountain streams mainly flowing on siliceous substrate. The Piemonte region includes 6 HERs: Inner Alps, Po plain (HER 56), Monferrato (HER 62), Piemonte Apennines (HER 63), Apennines N (HER 64) and Inner Alps S (HER 107). The Ligurian rivers belong to 2 HERs, Apennines $\mathrm{N}$ and Ligurian Alps (HER 122). The sites and samples analysed in the study area are summarized in Tab. 1.
For the analysis of the D. geminata distribution, 411 samples were examined to assess the presence/absence of this species. The Valle d'Aosta samples numbered 234, collected between 2007 and 2010 in a very wide altitudinal range (300-2000 $\mathrm{m}$ asl). The dataset for Piemonte consisted of 97 samples, all collected in 2010 at sites between 100 and $800 \mathrm{~m}$ asl, almost half of the stations belonging to HER 56 (Po plain). The remaining samples were collected in 2008-2010 in Liguria at altitudes between 2 and $965 \mathrm{~m}$ asl. Given the considerable size of this species, the criterion for discriminating between presence and absence was based on the examination of the whole slide. A distribution map was elaborated: for sites with seasonal replicates, D. geminata was considered present even when detected only once.

Water quality parameters at the sampling sites were provided by the environmental agencies (ARPA Valle d'Aosta and ARPA Liguria) and by Piemonte Region according to IRSA (1994) Italian Standard methods. For Valle d'Aosta, 134 of the 234 original samples were chosen based on the availability of water quality parameters. To highlight possible differences at sites with and without D. geminata, Mann-Whitney tests were performed for each of the following physical-chemical parameters: ammonium $\left(\mathrm{N}_{-} \mathrm{NH}_{4}^{+}\right)$, nitrate $\left(\mathrm{N}-\mathrm{NO}_{3}^{-}\right)$, total nitrogen (TKN), biochemical oxygen demand (BOD), chemical oxygen demand (COD), calcium $\left(\mathrm{Ca}^{++}\right)$, chloride $\left(\mathrm{Cl}^{-}\right)$, conductivity, total phosphorus (TP), total suspended solids (TSS), dissolved oxygen (DO), pH. For Piemonte, additional parameters (sulphates, alkalinity, magnesium, potassium, sodium) were available. Samples were divided into 5 groups, corresponding to the 5 HERs where $D$. geminata was detected, before the Mann-Whitney test was carried out on each group.

Some macroscopic blooms of $D$. geminata were ob-

Tab. 1. Number of sampling sites and samples used for the $D$. geminata distribution map and Mann-Whitney tests (presence/absence), and the calculation of the species optima inventories. In Valle d'Aosta region, several sites were sampled during all four years.

\begin{tabular}{|c|c|c|c|c|c|c|}
\hline & & & 2007 & 2008 & 2009 & 2010 \\
\hline \multirow[t]{4}{*}{ Valle d'Aosta } & Presence/absence of DGEM & no. sites & 17 & 24 & 26 & 68 \\
\hline & & no. samples & 34 & 39 & 27 & 134 \\
\hline & Inventories & no. sites & & & 22 & \\
\hline & & no. samples & & & 23 & \\
\hline \multirow{4}{*}{ Piemonte } & Presence/absence of DGEM & no. sites & & & & 97 \\
\hline & & no. samples & & & & 97 \\
\hline & Inventories & no. sites & & & & 97 \\
\hline & & no. samples & & & & 97 \\
\hline \multirow[t]{4}{*}{ Liguria } & Presence/absence of DGEM & no. sites & & 8 & 19 & 17 \\
\hline & & no. samples & & 12 & 34 & 34 \\
\hline & Inventories & no. sites & & 8 & 19 & 17 \\
\hline & & no. samples & & 12 & 34 & 34 \\
\hline
\end{tabular}

DGEM, D. geminata. 
served during samplings. Two sites with the most persistent blooms were monitored for a 5 -week period in order to analyse the effects of thick mat production on benthic communities (both macroinvertebrates and diatoms), and to highlight the most important physical and chemical parameters associated with blooms. We chose the Germanasca and Pellice rivers (Piemonte), performing sampling every 7 days for 5 weeks. Characterization of the two sites was based on water quality data provided by Regione Piemonte, supplemented with field data collected specifically for this study, namely bed velocity, water depth (three replicates in the same transect), chlorophyll $a$ and $\mathrm{pH}$. Chlorophyll $a$ was analysed according to the procedure proposed in Bona et al. (2008); periphyton for the analyses was obtained by scraping a known substrate surface (at least $20 \mathrm{~cm}^{2}$ ) from cobbles. The samples were immediately filtered (Whatman GFC) and stored frozen in the dark until analysis. Bed velocity $(0.05 \mathrm{~m}$ from the bottom) was measured with a current meter (Mod RHCM Idromar). We took three velocity measurements for each site following the diatom sampling transect.

Ten diatom and macroinvertebrate samples were collected. The macroinvertebrates were sampled with a handnet sampler with a $250 \mu \mathrm{m}$ mesh according to the procedure suggested by Ghetti (1997). Macroinvertebrates were always collected along the same transect during the whole survey in order to avoid spatial variability of the community composition. When possible, the collected organisms were identified in the field to the family or genus level; otherwise they were preserved in $70 \%$ alcohol and analysed under a stereo-microscope. Each identified taxon was assigned to the respective functional feeding groups (Merrit and Cummins, 1996) and respiratory system. Diatom samplings and treatments followed the procedure proposed in the guidelines for routine monitoring with diatoms (EN Norm 13946; UNI, 2005). Diatoms were identified mainly according to Blanco et al. (2010), Hofmann et al. (2011); Krammer (1997a, 1997b, 2000, 2002, 2003), Krammer and Lange-Bertalot (1986, 1991a, 1991b), Lange-Bertalot (2001), Lange-Bertalot and Metzeltin (1996), Lavoie et al. (2008), Reichardt (1999) and Werum and Lange-Bertalot (2004). Each identified taxon was assigned to an ecological guild following Berthon et al. (2011). Mann-Whitney tests were performed to assess differences between bloom/no bloom samples in terms of macroinvertebrate community (metrics: number of families, feeding functional groups and respiratory systems) and diatom community (taxa composition, guilds).

Periphyton samples for the diatom community analysis were collected at all the above-mentioned sites in Piemonte and Liguria and at 22 sites in Valle d'Aosta following the procedure and the bibliographic references described above. We focused on the presence and autecology of some particular taxa due to their floristic and biogeographical interest. For these taxa, we calculated the values of the autecological parameters in the study area with regard to main water quality variables: $\mathrm{N}$ $\mathrm{NH}_{4}^{+}, \mathrm{N}^{-\mathrm{NO}_{3}}{ }_{3}$, TKN, TP, BOD, $\mathrm{Ca}^{++}, \mathrm{Cl}^{-}$, conductivity, $\mathrm{pH}, \mathrm{TSS}, \mathrm{DO}$ and temperature. For each variable, we calculated the environmental range (i.e. the minimum and maximum values for that variable in all the samples in which the species was recorded), optimum and tolerance. Optima were calculated using the weighted average method proposed by Birks et al. (1990), whereby the ecological optimum for a given species is the average of the values observed at the sites where the species is present weighted by the relative abundances of the species in each sample.

\section{RESULTS}

\section{Distribution of $D$. geminata in North-Western Italy}

A distribution map of $D$. geminata in NW Italy was produced on the basis of the 411 samples (Fig. 1). In Valle d'Aosta, the first records of $D$. geminata overlap with the beginning of the diatom survey carried out by the environmental agency (ARPA VdA) in 2007. In that year, $D$. geminata was observed all along the Dora Baltea river from Dolonne to Point Saint Martin (on the border with Piemonte region), and in 7 lateral valleys including the highest sampling site, Marmore river in Valtournenche (1830 $\mathrm{m}$ asl). Subsequent studies highlighted the rapid spread of D. geminata all over the region (Falasco et al., 2008 a,b). In 2008, D. geminata colonized two more rivers, Artavanaz and Buthier. In total, D. geminata was present at least once at 46 sites out of 85. Despite this, no macroscopic bloom was ever observed in this region. In general, sites with the presence of $D$. geminata show lower BOD, $\mathrm{Ca}^{++}$and TKN and slightly higher $\mathrm{N}_{-} \mathrm{NO}_{3}^{-}$, TP, DO, and $\mathrm{Cl}^{-}$. The geological substrate is not a key feature for D. geminata, which is able to colonize both siliceous and calcareous streams. In general, the ecological status of Valle d'Aosta rivers is high, and all watercourses can be considered oligotrophic, with circumneutral or slightly basic $\mathrm{pH}$. The only disturbance affecting these rivers is probably physical, with strong morphological modifications of riverbanks and bank tops. In Piemonte, we found D. geminata at 20 sampling sites out of $97 ; 17$ of the 20 positive sites were characterized by artificial flow regulators, in particular concrete or rock weirs. Land use surrounding the sites generally comprised pastures and agricultural areas, and low urbanization. $D$. geminata preferred sites with lower alkalinity, $\mathrm{Ca}^{++}, \mathrm{Cl}^{-}$,

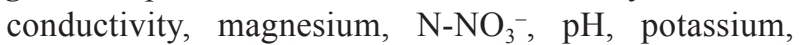
sodium, sulphates, and TKN. In Liguria, the diatom survey started in 2008 and D. geminata was detected in 15 samples out of 80 (11 sampling sites out of 36) in three years of monitoring. 


\section{Environmental features related to the presence/absence of $D$. geminata}

The Mann-Whitney test applied to the HERs where D. geminata was present highlighted the importance of different environmental parameters (Tab. 2). In particular, the nutrient content in the Alpine HER did not seem a key factor in determining the presence of D. geminata, probably due to the general oligotrophic condition. On the other hand, BOD and $\mathrm{Cl}^{-}$differed between the two groups of sites, although the ranges of variation were quite narrow (maximum value for BOD was $5 \mathrm{mg} \mathrm{L}^{-1}$; $\mathrm{Cl}^{-}$concentration was generally lower than $25 \mathrm{mg} \mathrm{L}^{-1}$ ). In the Po plain, $\mathrm{Ca}^{++}, \mathrm{Cl}^{-}$and conductivity were important variables for the presence of $D$. geminata, which was mainly restricted to non-calcareous sites with low conductivity and $\mathrm{Cl}^{-}$. In the North Apennines, the nitrogen level was an important factor, since the presence of
D. geminata was restricted to waters with low $\mathrm{N}-\mathrm{NO}_{3}{ }^{-}$ and TKN contents.

\section{Macroscopic blooms of $D$. geminata}

Macroscopic blooms were detected in some rivers in Piemonte. In particular, thick mats were observed for several months in the Germanasca and Pellice rivers. From a general evaluation of the historical data, both stations present high water quality in terms of nutrient and salinity content, with the exception of $\mathrm{N}-\mathrm{NO}_{3}{ }^{-}$whose concentrations were slightly higher in the Pellice river. The low calcium content reflected the presence of a siliceous substrate. The $\mathrm{pH}$ was circumneutral, always between 6.45 and 8 ; TSS were always very low. Temperature was generally low during the survey, with a peak of $14.4^{\circ} \mathrm{C}$ in June. During our study, chlorophyll a values were be-

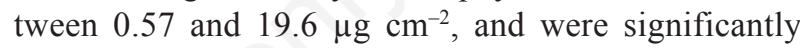

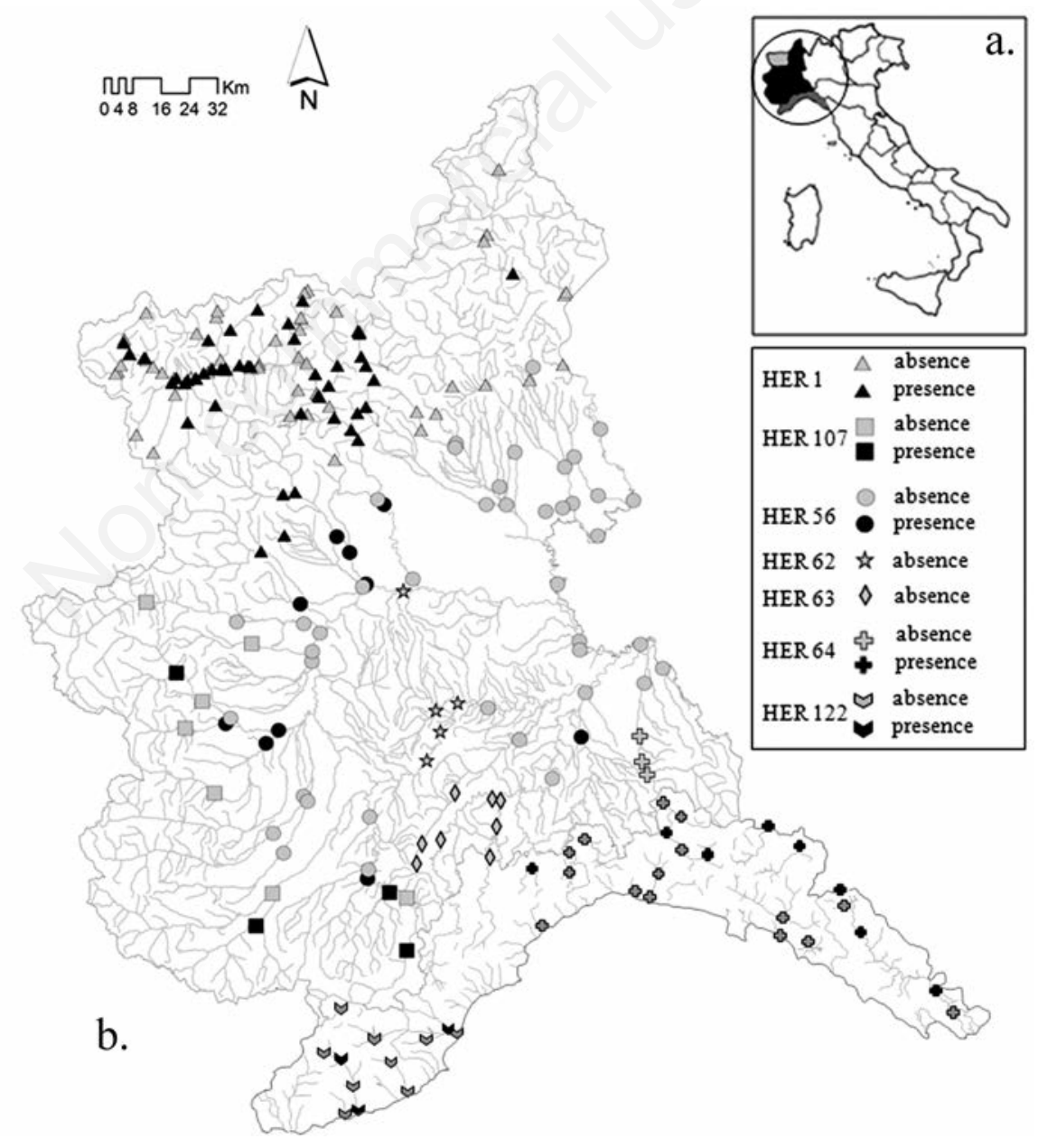

Fig. 1. Distribution map of Didymosphenia geminata in the study area, with classification of sampling sites based on the HER to which they belong. a) geographical position of the study area; b) Valle d'Aosta (2007-2010); Piemonte (2010); Liguria (2008-2010). 
higher during $D$. geminata blooms $(\mathrm{P}<0.05)$. Bed velocity never exceeded $1.5 \mathrm{~m} \mathrm{~s}^{-1}$, and blooms were generally observed during high-speed flow conditions (mean value $0.91 \mathrm{~m} \mathrm{~s}^{-1}$ ). On the other hand, there was a negative relation between cell density and water depth, as blooms were never observed in water deeper than $0.35 \mathrm{~m}$. There was no difference in the number of families or genera making up the macroinvertebrate communities during the blooms or in normal conditions. Despite this, we observed an increase of the number of taxa belonging to Diptera and a significant decrease of Tricoptera, in particular Hydropsychidae and Heptageniidae, during D. geminata blooms. In general, we observed an increase of collectors and a decrease of scrapers. In terms of respiratory groups, there was no increase of taxa characterized by cutaneous respiration with respect to those with branchial respiration (i.e. external tracheal gills).

In general, diatom communities consisted of oligo and $\beta$-mesosaprobous taxa typical of mountain streams, and denoting good water quality, i.e. Achnanthidium pyrenaicum (Hustedt) Kobayasi, Achnanthidium minutissimum species group, Encyonema silesiacum (Bleisch) Mann, Gomphonema elegantissimum Reichardt and
Lange-Bertalot, Gomphonema tergestinum Fricke, and Reimeria sinuata (Gregory) Kociolek and Stoermer. The abundance of some species decreased when $D$. geminata produced blooms. In particular, A. minutissimum, G. elegantissimum and G. tergestinum were inhibited by massive mats. On the other hand, Diatoma mesodon (Ehrenberg) Kutzing increased in abundance when a $D$. geminata bloom was present. Overall, there was an increased abundance of motile taxa and erect forms when a bloom was present, while stalked and prostrate forms decreased. However, no statistically significant differences were observed among guilds in the case of a bloom.

\section{Non-indigenous taxa: distribution and site characterisation}

In total, 200 samples were collected for the diatom community analysis from 2008 to 2010, and 305 taxa were identified. The most abundant taxa and present in at least $50 \%$ of the samples are (in order of abundance): $A$. minutissimum, A. pyrenaicum, Nitzschia fonticola Grunow, R. sinuata, E. silesiacum, Cocconeis placentula var. euglypta Ehrenberg, Nitzschia dissipata (Kützing) Grunow, Amphora pediculus (Kützing) Grunow, Ency-

Tab. 2. Mann Whitney test applied to the different hydroecoregions. Grouping variable: presence of $D$. geminata. In italics: significant difference $(\mathrm{P}<0.05)$. The Monferrato and Piemonte Apennines hydroecoregions were excluded from the analysis since $D$. geminata was not detected in any of the sampling sites.

\begin{tabular}{|c|c|c|c|c|c|c|c|c|c|}
\hline & HER & Mann- Whitney U & $\mathrm{P}$ & HER & Mann- Whitney U & $\mathrm{P}$ & HER & Mann- Whitney U & $\mathrm{P}$ \\
\hline $\mathrm{N}-\mathrm{NH}_{4}^{+}$ & Alpine & 2330.5 & 0.122 & Po plain & 198 & 0.867 & Apennines $\mathrm{N}$ & 154.5 & 0.214 \\
\hline $\mathrm{N}^{-\mathrm{NO}_{3}^{-}}$ & & 2392 & 0.270 & & 138 & 0.112 & & 48.5 & 0.000 \\
\hline TKN & & 2349.5 & 0.144 & & 128 & 0.068 & & 79.5 & 0.004 \\
\hline BOD & & 1950.5 & 0.004 & & 148 & 0.150 & & 165 & 0.432 \\
\hline COD & & 2692.5 & 0.894 & & 154 & 0.204 & & 191 & 0.826 \\
\hline $\mathrm{Ca}^{++}$ & & 2403.5 & 0.290 & & 122.5 & 0.049 & & 101.5 & 0.618 \\
\hline $\mathrm{Cl}^{-}$ & & 1934.5 & 0.003 & & 103.5 & 0.016 & & 154.5 & 0.313 \\
\hline Conductivity & & 2382.5 & 0.255 & & 109.5 & 0.023 & & 178 & 0.522 \\
\hline TP & & 2317 & 0.128 & & 131.5 & 0.073 & & 145 & 0.114 \\
\hline SS & & 2490.5 & 0.408 & & 145.5 & 0.145 & & 194 & 0.790 \\
\hline DO & & 2384 & 0.257 & & 149 & 0.184 & & 191.5 & 0.836 \\
\hline $\mathrm{pH}$ & & 2525 & 0.486 & & 179 & 0.537 & & 136 & 0.098 \\
\hline Temperature & & 2239.5 & 0.074 & & 204.5 & 0.991 & & 158 & 0.265 \\
\hline $\mathrm{N}-\mathrm{NH}_{4}^{+}$ & Inner Alps S & 198 & 0.262 & Ligurian Alps & 12 & 0.501 & & & \\
\hline $\mathrm{N}^{-\mathrm{NO}_{3}}{ }^{-}$ & & 138 & 0.071 & & 2 & 0.060 & & & \\
\hline TKN & & 128 & 0.218 & & 42.5 & 0.300 & & & \\
\hline BOD & & 148 & 0.229 & & 55.5 & 0.778 & & & \\
\hline COD & & 154 & 0.189 & & 48 & 0.359 & & & \\
\hline $\mathrm{Ca}^{++}$ & & 122.5 & 0.850 & & 28 & 0.657 & & & \\
\hline $\mathrm{Cl}^{-}$ & & 103.5 & 0.450 & & 54 & 0.950 & & & \\
\hline Conductivity & & 109.5 & 1.000 & & 42 & 0.299 & & & \\
\hline TP & & 131.5 & 0.548 & & 49 & 0.314 & & & \\
\hline SS & & 145.5 & 0.303 & & 35 & 0.166 & & & \\
\hline DO & & 149 & 0.776 & & 31 & 0.094 & & & \\
\hline $\mathrm{pH}$ & & 179 & 0.705 & & 52 & 0.481 & & & \\
\hline Temperature & & 204.5 & 0.059 & & 53.5 & 0.537 & & & \\
\hline
\end{tabular}

HER, hydroecoregion; BOD, biochemical oxygen demand; COD, chemical oxygen demand; TP, total phosphorus; SS, suspended solids; DO, dissolved oxygen. 
onema minutum (Hilse) Mann. In addition to D. geminata, the analysis focused on four taxa poorly known in Italy and with a potentially expanding distributional range. They are, in order of occurrence, Reimeria uniseriata Sala Guerrero and Ferrario, Achnanthidium subhudsonis (Hustedt) Kobayasi, Cymbella tropica Krammer and Mayamaea cahabaensis Morales and Manoylov. A map with the distribution of these taxa is reported in Fig. 2. Tab. 3 summarizes data on records of D. geminata, A. subhudsonis, C. tropica, M. cahabaensis, and R. uniseriata in the study area. Light and electron microscope photographs of the last four taxa are shown in Fig. 3.

A. subhudsonis was recorded only in Piemonte, at 15 sites distributed mainly in the northern part of the region (Inner Alps and Po plain; HERs 1 and 56). The relative abundance of $A$. subhudsonis reached $20 \%$ in the Chiusella and Ticino rivers, highlighting the invasive be- haviour of the species. C. tropica was widespread throughout Piemonte and reached its highest abundance in the Chisone river (25.7\%). Several rivers were contemporaneously affected by $A$. subhudsonis and C. tropica (i.e. Cervo, Chiusella, Roggia Busca, and Sessera). These two non-indigenous taxa were mainly recorded at sites with similar environmental and chemical features. All the sites were surrounded by agricultural zones (cereal production or rice paddies). In some cases, the presence of industrial areas (chemical, metallurgical or paper mills) affected the water chemistry of sampling sites, e.g., presence of heavy metals in the water column $(\mathrm{Cd}, \mathrm{Cr}, \mathrm{Cu}$, $\mathrm{Hg}, \mathrm{Ni}, \mathrm{Pb}$, and $\mathrm{Zn}$, data provided by Regione Piemonte). A. subhudsonis seems to be able to survive in habitats with reduced light penetration; indeed the transparency of the water column was limited or nil in some cases. Although cobbles were the dominant substrate where $A$. subhudso-



Fig. 2. Distribution map of Achnanthidium subhudsonis (Hustedt) Kobayasi, Cymbella tropica Krammer, Mayamaea cahabaensis Morales and Manoylov, Reimeria uniseriata Sala Guerrero and Ferrario in Piemonte and Liguria updated to 2010. These taxa were not detected in Valle d'Aosta. 
Tab. 3. Location (Universal Transverse Mercator projection, European Datum ED50) and hydroecoregions classification of sampling sites where the studied species were detected.

\begin{tabular}{|c|c|c|c|c|c|c|c|c|c|c|c|}
\hline Region & Year & HER & River & Location & UTM_X & UTM_Y & DGEM & RUNI & MCAH & ADSH & CTRO \\
\hline \multirow[t]{46}{*}{ Valle d'Aos } & 2010 & 1 & Buthier & Ferreres & 379980 & 5082431 & + & & & & \\
\hline & 2010 & 1 & Colombaz & Foce & 348164 & 5068787 & + & & & & \\
\hline & 2010 & 1 & Petit Monde & Loditor & 388730 & 5078545 & + & & & & \\
\hline & $2009 ; 2010$ & 1 & Savara & Introd & 359447 & 5061619 & + & & & & \\
\hline & 2008 & 1 & Artanavaz & Allein & 366065 & 5073747 & + & & & & \\
\hline & $2007 ; 2008$ & 1 & Ayasse & Hone & 401716 & 5051820 & + & & & & \\
\hline & 2010 & 1 & Ayasse & Vignat & 392283 & 5053152 & + & & & & \\
\hline & 2008 & 1 & Buthier & Thoules & 372265 & 5076705 & + & & & & \\
\hline & 2010 & 1 & Buthier & Foce & 370934 & 5065780 & + & & & & \\
\hline & 2010 & 1 & Chateau de Quart & Foce & 374852 & 5066641 & + & & & & \\
\hline & 2010 & 1 & Clusellaz & Foce & 364744 & 5064396 & + & & & & \\
\hline & 2010 & 1 & Comboè & Foce & 370924 & 5065430 & + & & & & \\
\hline & $2007 ; 2008 ; 2010$ & 1 & Dora Baltea & Pont Saint Martin & 406504 & 5048368 & + & & & & \\
\hline & $2007 ; 2008 ; 2009 ; 2010$ & 1 & Dora Baltea & Pré Saint Didier & 343788 & 5069928 & + & & & & \\
\hline & 2010 & 1 & Dora Baltea & Champex & 343400 & 5070183 & + & & & & \\
\hline & 2007; 2008; 2009 & 1 & Dora Baltea & Aosta & 367160 & 5065446 & + & & & & \\
\hline & 2010 & 1 & Dora Baltea & Monte CAS & 369677 & 5065550 & + & & & & \\
\hline & 2010 & 1 & Dora Baltea & Plan Felinaz & 370556 & 5065479 & + & & & & \\
\hline & 2010 & 1 & Dora Baltea & Les Iles & 377937 & 5066359 & + & & & & \\
\hline & 2010 & 1 & Dora Baltea & Quart & 377284 & 5066432 & + & & & & \\
\hline & 2010 & 1 & Dora Baltea & Favà & 397169 & 5058181 & + & & & & \\
\hline & 2010 & 1 & Dora Baltea & Dolonne & 342082 & 5073104 & + & & & & \\
\hline & 2010 & 1 & Dora Baltea & Sarriod de la tour & 362389 & 5062981 & + & & & & \\
\hline & 2010 & 1 & Dora Baltea & Morgex & 347808 & 5068637 & + & & & & \\
\hline & 2010 & 1 & Dora Baltea & Marais & 348565 & 5068028 & + & & & & \\
\hline & $2007 ; 2009 ; 2010$ & 1 & Dora Baltea & Borgo di Montjovet & 396297 & 5064175 & + & & & & \\
\hline & $2007 ; 2008$ & 1 & Dora di Rhemes & Villeneuve & 360098 & 5062498 & + & & & & \\
\hline & 2007 & 1 & Dora di Valgrisenche & Leverogne & 355768 & 5061657 & + & & & & \\
\hline & 2010 & 1 & Dora di Valgrisenche & Foce & 356993 & 5062968 & + & & & & \\
\hline & $2007 ; 2008$ & 1 & Evançon & Arcesaz & 402595 & 5066504 & + & & & & \\
\hline & 2010 & 1 & Evançon & Isollaz & 400070 & 5060859 & + & & & & \\
\hline & 2010 & 1 & Evançon & Foce & 397572 & 5057732 & + & & & & \\
\hline & 2007; 2008; 2009 & 1 & Grand Eyvia & Cogne & 368074 & 5055371 & + & & & & \\
\hline & 2010 & 1 & Grand Eyvia & Foce & 362692 & 5062829 & + & & & & \\
\hline & 2007 & 1 & Lys & Gaby & 412950 & 5062582 & + & & & & \\
\hline & $2008 ; 2010$ & 1 & Lys & Fontainemore & 410655 & 5054880 & + & & & & \\
\hline & 2010 & 1 & Lys & Bessesse & 408205 & 5053124 & + & & & & \\
\hline & 2010 & 1 & Lys & Tschossil & 410657 & 5066522 & + & & & & \\
\hline & 2010 & 1 & Lys & Tache & 408821 & 5075594 & + & & & & \\
\hline & 2010 & 1 & Lys & Ejo & 408451 & 5076384 & + & & & & \\
\hline & 2010 & 1 & Lys & Tschoarde & 409265 & 5069137 & + & & & & \\
\hline & 2009 & 1 & Lys & Fontainemore & 410655 & 5054880 & + & & & & \\
\hline & 2008 & 1 & Lys & Pont Saint Martin & 341970 & 5049975 & + & & & & \\
\hline & 2008 & 1 & Marmore & Filey & 390403 & 5074245 & + & & & & \\
\hline & 2007 & 1 & Marmore & Perrères & 392683 & 5084973 & + & & & & \\
\hline & 2010 & 1 & Savara & Degioz & 360182 & 5050509 & + & & & & \\
\hline \multirow[t]{10}{*}{ Piemonte } & 2010 & 1 & Malone & Rocca Canavese & 387584 & 5018405 & + & & & & \\
\hline & 2010 & 1 & Stura di Lanzo & Lanzo Torinese & 380983 & 5013876 & + & & & & \\
\hline & 2010 & 1 & Curone & Pontecurone & 494618 & 4980962 & + & & & & \\
\hline & 2010 & 1 & Dora Baltea & Settimo & 408403 & 5045493 & + & & & & \\
\hline & 2010 & 1 & Orco & Pont-Canavese & 387187 & 5030109 & + & & & & \\
\hline & 2010 & 1 & S.Bernardino & Verbania & 466732 & 5086599 & & & & & + \\
\hline & 2010 & 1 & S. Giovanni di Intra & Verbania & 467274 & 5087417 & & & & + & \\
\hline & 2010 & 1 & Sessera & Borgosesia & 444512 & 5061036 & & & & + & + \\
\hline & 2010 & 1 & Toce & Premosello-Chiovenda & 452169 & 5092720 & + & & & & \\
\hline & 2010 & 56 & Malesina & San Giusto Canavese & 406014 & 5013548 & + & & & & \\
\hline
\end{tabular}

To be continued on next page. 
Tab. 3. Continued from previous page.

\begin{tabular}{|c|c|c|c|c|c|c|c|c|c|c|c|}
\hline Region & Year & HER & River & Location & UTM_X & UTM_Y & DGEM & RUNI & $\mathrm{MCAH}$ & ADSH & CTRO \\
\hline \multirow[t]{40}{*}{ Piemonte } & 2010 & 56 & Orba & Casal Cermelli & 471572 & 4961515 & + & & & & + \\
\hline & 2010 & 56 & Orco & Chivasso & 410724 & 5004642 & + & & & & + \\
\hline & 2010 & 56 & Pellice & Villafranca Piemonte & 385855 & 4963372 & + & & & & + \\
\hline & 2010 & 56 & Pellice & Garzigliana & 370974 & 4965289 & + & & & & \\
\hline & 2010 & 56 & Agogna & Briga Novarese & 457896 & 5066137 & & & & + & \\
\hline & 2010 & 56 & Agogna & Novara & 469024 & 5027557 & & & & + & \\
\hline & 2010 & 56 & Belbo & Castelnuovo Belbo & 454035 & 4960704 & & + & & & \\
\hline & 2010 & 56 & Bormida & Alessandria & 472683 & 4974110 & & + & & & \\
\hline & 2010 & 56 & Ceronda & Venaria & 392087 & 4999203 & + & & & & + \\
\hline & 2010 & 56 & Cervo & Cossato & 435884 & 5043337 & & & & + & + \\
\hline & 2010 & 56 & Chisone & Garzigliana & 372268 & 4966857 & & & & & + \\
\hline & 2010 & 56 & Chiusella & Strambino & 413982 & 5028585 & & & & + & + \\
\hline & 2010 & 56 & Dora Baltea & Saluggia & 423844 & 5006090 & & + & & & \\
\hline & 2010 & 56 & Dora Baltea & Strambino & 415703 & 5027182 & + & & & & \\
\hline & 2010 & 56 & Ellero & Bastia Mondovi' & 411066 & 4921394 & + & & & & \\
\hline & 2010 & 56 & Grana & Valenza & 471094 & 4986167 & & + & & + & \\
\hline & 2010 & 56 & Grana-Mellea & Savigliano & 394086 & 4943259 & & + & & & \\
\hline & 2010 & 56 & Marchiazza & Collobiano & 450367 & 5027114 & & & & + & \\
\hline & 2010 & 56 & Orco & Feletto & 402425 & 5018044 & + & & & & \\
\hline & 2010 & 56 & Po & Villafranca Piemonte & 382362 & 4959682 & + & & & & \\
\hline & 2010 & 56 & Po & Valenza & 471025 & 4988687 & & + & & & \\
\hline & 2010 & 56 & Roggia Biraga & Novara & 466243 & 5026191 & & + & + & & \\
\hline & 2010 & 56 & Roggia Busca & Casalino & 461450 & 5025218 & & & & + & + \\
\hline & 2010 & 56 & Roggia Mora & San Pietro Mosezzo & 466861 & 5037793 & & & & + & \\
\hline & 2010 & 56 & Scrivia & Castelnuovo & 489345 & 4976740 & & + & & & \\
\hline & 2010 & 56 & Sesia & Motta De' Conti & 464813 & 5004710 & & & & + & \\
\hline & 2010 & 56 & Strona & Cosstato & 436176 & 5044496 & & & & + & \\
\hline & 2010 & 56 & Tanaro & Castello Di Annone & 445180 & 4969789 & & + & + & & \\
\hline & 2010 & 56 & Terdoppio & Caltignaga & 469539 & 5040650 & & & & + & \\
\hline & 2010 & 56 & Terdoppio & Trecate & 476323 & 5029754 & & & & + & \\
\hline & 2010 & 56 & Ticino & Oleggio & 476900 & 5048490 & & & & & + \\
\hline & 2010 & 56 & Ticino & Cerano & 486288 & 5028271 & & & & + & \\
\hline & 2010 & 62 & Triversa & Asti & 430365 & 4969192 & & + & & & \\
\hline & 2010 & 63 & Belbo & Feisoglio & 426535 & 4931207 & & + & & & \\
\hline & 2010 & 63 & Bormida di Millesimo & Monastero Bormida & 446382 & 4943933 & & + & & & \\
\hline & 2010 & 107 & Corsaglia & Lesegno & 417324 & 4917401 & + & & & & \\
\hline & 2010 & 107 & Germanasca & Pomaretto & 357062 & 4979691 & + & & & & \\
\hline & 2010 & 107 & Tanaro & Priola & 422210 & 4900947 & + & & & & \\
\hline & 2010 & 107 & Tanaro & Ceva & 422163 & 4915889 & & + & & & \\
\hline & 2010 & 107 & Vermenagna & Roccavione & 379528 & 4907933 & + & & & & \\
\hline \multirow[t]{15}{*}{ Liguria } & $2008 ; 2009$ & 64 & Aveto & Rezzoaglio & 532636 & 4933287 & + & & & & \\
\hline & 2009 & 64 & Erro & Sassello & 457511 & 4926456 & + & + & & & \\
\hline & 2008 & 64 & Magra & Sarzana & 575141 & 4884454 & & + & & & \\
\hline & 2008 & 64 & Pentemina & Montoggio & 506581 & 4930596 & + & & & & \\
\hline & 2010 & 64 & Scrivia & Ronco Scrivia & 495341 & 4936937 & + & & & & \\
\hline & 2009 & 64 & Taro & Tornolo & 544050 & 4920477 & + & & & & \\
\hline & 2008 & 64 & Trebbia & Gorreto & 523551 & 4939317 & + & & & & \\
\hline & 2010 & 64 & Vara & Vezzano Ligure & 570955 & 4889831 & + & & & & \\
\hline & 2008 & 64 & Vara & Varese Ligure & 549897 & 4906958 & + & & & & \\
\hline & 2010 & 64 & Varenna & Genova & 485911 & 4919727 & & + & & & \\
\hline & 2010 & 122 & Argentina & Molini di Triora & 404311 & 4869936 & + & & & & \\
\hline & 2010 & 122 & Argentina & Taggia & 408361 & 4854486 & + & & & & \\
\hline & 2009 & 122 & Centa & Albenga & 436329 & 4878102 & & + & & & \\
\hline & 2009 & 122 & Lerrone & Garlenda & 427872 & 4876043 & & + & & & \\
\hline & 2010 & 122 & Neva & Albenga & 434716 & 4878630 & + & & & & \\
\hline
\end{tabular}

HER, hydroecoregions; UTM, universal transverse mercator; DGEM, D. geminata; RUNI, R. uniseriata; MCAH, M. cahabaensis; ADSH, A. subhudsonis; $C T R O$, C. tropica. 
nis and C. tropica were collected, we noticed a significant percentage of finer materials (gravel, sand, and silt), especially at sites with $A$. subhudsonis. Water velocity was generally low, typical of lowland rivers, and the mean depth was approximately $25 \mathrm{~cm}$. The agricultural activities slightly affected the water quality in terms of nitrates. M. cahabaensis was detected in two rivers far from each other but belonging to the same HER (Po plain). Although different in size and substrate, the two rivers have common characteristics in terms of anthropogenic pressures, mainly related to intensive agriculture. $R$. uniseriata currently appears to have a rather wide distribution, as the 18 stations in which it was found belong to all the HER in- cluded in the study area. The affected rivers have very disparate characteristics, often with a depositional character.

\section{Autecology of taxa of special interest}

Tab. 4 reports the comparison between the ranges of the main water parameters calculated for the whole database (200 records covering the entire study area), and the range of the same parameters where the single taxon was recorded. Optimum and tolerance values for each species are also reported.

The samples covered a wide range of trophic levels for phosphorus, nitrogen, and organic loading. The min-
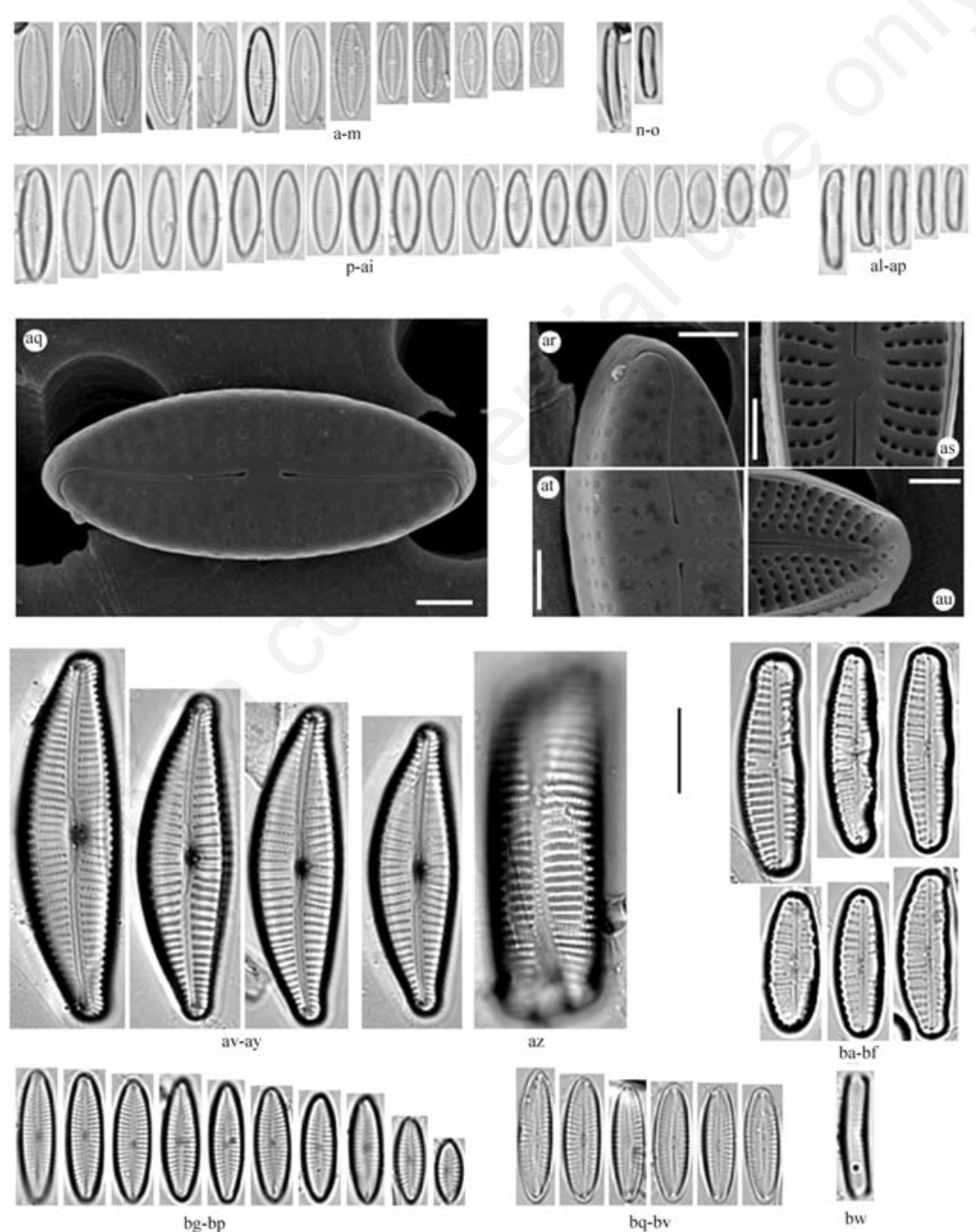

Fig. 3. Taxa of particular interest detected during the surveys. Light micrographs of different populations of M. cahabaensis. Tanaro river: valvar (a-m) and girdle (n-o) views. Mincio river: valvar (p-ai) and girdle (al-ap) views. Scanning electron micrographs of $M$. $c a$ habaensis from Mincio river. External view (aq). Detail of the valve apex showing the terminal raphe ending: external (ar) and internal (au) views. Details of the central part of valve: external (at) and internal (as) views. Light micrographs of C. tropica: valvar (av-ay) and girdle (az) views; $R$. uniseriata (ba-bf); A. subhudsonis: rapheless (bg-bp) and raphe (bq-bv) valves; girdle view (bw). LM scale bar: $10 \mu \mathrm{m}$; SEM scale bar: $1 \mu \mathrm{m}$. 
eral content was generally low, as highlighted by conductivity, $\mathrm{Ca}^{++}$and $\mathrm{Cl}^{-}$, with the exception of sites in the Ligurian catchments. $\mathrm{pH}$ was generally between neutral and alkaline values. TSS content was generally moderate (below $100 \mathrm{mg} \mathrm{L}^{-1}$ ), with values above 100 confined to the Po plain (HER 56), characterized by fine substrate.

A. subhudsonis showed a marked preference for waters low in ammonia, TP and BOD, while its optimum for $\mathrm{N}_{-} \mathrm{NO}_{3}{ }^{-}$corresponded to a mesotrophic-eutrophic condition. Its optimum for conductivity and $\mathrm{Cl}^{-}$was low but the range for conductivity was wide (up to $407 \mu \mathrm{S}$ $\left.\mathrm{cm}^{-1}\right)$. $\mathrm{pH}$ was circumneutral. This species showed a high tolerance to TSS (up to $202 \mathrm{mg} \mathrm{L}^{-1}$ ), with a preference for low values. C. tropica seemed to tolerate quite high nitrate concentrations, although the optimum value was low; regarding the other nutrients and BOD, this taxon was found in waters with oligotrophic values. It showed a rather narrow range for conductivity, $\mathrm{Cl}^{-}$, and
TSS. D. geminata generally colonized oligotrophic stretches with low organic loading, a non-calcareous substrate and low TSS values. Data on conductivity showed an optimum at $229 \mu \mathrm{S} \mathrm{cm}{ }^{-1}$. Despite this, a rather high ecological amplitude emerged from our data. The autecological data on M. cahabaensis must be considered preliminary, due to the very limited distribution in the study area at the time of the sampling (20082010). This taxon showed a higher preference for nutrient and organic enrichment than the other taxa. The mineral content at the stations with this species was moderate. Its presence did not seem to be influenced by the TSS concentration. $R$. uniseriata seems to be a euryoecious species typical of lowland stretches. In many cases, the range of environmental parameters in which it was present overlapped with that of the entire database. The nutrient and BOD optima corresponded to a II - III class. The optimum for calcium was $53 \mathrm{mg} \mathrm{L}^{-1}$ with a wide range (18-109 $\left.\mathrm{mg} \mathrm{L}^{-1}\right)$.

Tab. 4. Ranges, optima (in italics) and tolerance (in parentheses) values for nutrients, biochemical oxygen demand, calcium, chloride, conductivity, $\mathrm{pH}$, total suspended solids, dissolved oxygen and temperature calculated from 200 samples.

\begin{tabular}{|c|c|c|c|c|c|c|}
\hline & $\begin{array}{l}\mathrm{N}-\mathrm{NH}_{3} \\
\left(\mathrm{mg} \mathrm{L}^{-1}\right)\end{array}$ & $\begin{array}{l}\mathrm{N}-\mathrm{NO}_{3} \\
\left(\mathrm{mg} \mathrm{L}^{-1}\right)\end{array}$ & $\begin{array}{c}\text { TKN } \\
\left(\mathrm{mg} \mathrm{L}^{-1}\right)\end{array}$ & $\begin{array}{c}\mathrm{TP} \\
\left(\mathrm{mg} \mathrm{L}^{-1}\right)\end{array}$ & $\begin{array}{c}\text { BOD } \\
\left(\mathrm{mg} \mathrm{L}^{-1}\right)\end{array}$ & $\begin{array}{c}\mathrm{Ca}^{++} \\
\left(\mathrm{mg} \mathrm{L}^{-1}\right)\end{array}$ \\
\hline $\begin{array}{l}\text { Range for the } \\
\text { whole study area }\end{array}$ & $0.000-2.470$ & $0.05-7.1$ & $0.025-8.15$ & $0.002-0.657$ & $0.5-20$ & $0.25-120$ \\
\hline $\mathrm{ADSH}$ & $\begin{array}{l}0.015-0.140 \\
0.04(0.035)\end{array}$ & $\begin{array}{c}0.4-3.4 \\
1.62(0.77)\end{array}$ & $\begin{array}{c}1.7-5.3 \\
2.58(0.612)\end{array}$ & $\begin{array}{l}0.003-0.203 \\
0.05(0.043)\end{array}$ & $\begin{array}{c}1-7.3 \\
1.66(1.22)\end{array}$ & $\begin{array}{c}4.4-62.1 \\
19.9(8.96)\end{array}$ \\
\hline CTRO & $\begin{array}{l}0.015-0.097 \\
0.02(0.012)\end{array}$ & $\begin{array}{c}0.5-3.0 \\
0.81(0.523)\end{array}$ & $\begin{array}{c}0.95-3.70 \\
1.48(0.762)\end{array}$ & $\begin{array}{l}0.003-0.053 \\
0.04(0.016)\end{array}$ & $\begin{array}{c}1.0-3.7 \\
1.23(0.678)\end{array}$ & $\begin{array}{c}8.1-63.2 \\
29.1(12.95)\end{array}$ \\
\hline DGEM & $\begin{array}{c}0.005-0.380 \\
0.03(0.03)\end{array}$ & $\begin{array}{c}0.14-3.03 \\
0.54(0.57)\end{array}$ & $\begin{array}{c}0.24-3.70 \\
1.06(0.838)\end{array}$ & $\begin{array}{l}0.015-0.171 \\
0.03(0.025)\end{array}$ & $\begin{array}{c}0.50-3.51 \\
1.16(0.703)\end{array}$ & $\begin{array}{r}0.25-65.10 \\
28.6(21.97)\end{array}$ \\
\hline MCAH & $\begin{array}{l}0.075-0.177 \\
0.17(0.044)\end{array}$ & $\begin{array}{c}1.4-3.1 \\
1.58(0.745)\end{array}$ & $\begin{array}{c}3.07-4.83 \\
3.25(0.759)\end{array}$ & $\begin{array}{c}0.1-0.3 \\
0.27(0.082)\end{array}$ & $\begin{array}{c}3.0-4.0 \\
3.1(0.430)\end{array}$ & $\begin{array}{c}33.9-68.7 \\
37.5(14.97)\end{array}$ \\
\hline \multirow[t]{2}{*}{ RUNI } & $\begin{array}{l}0.003-2.470 \\
0.13(0.460)\end{array}$ & $\begin{array}{c}0.005-4.450 \\
1.26(1.01)\end{array}$ & $\begin{array}{c}0.46-5.95 \\
2.38(1.732)\end{array}$ & $\begin{array}{l}0.015-0.657 \\
0.09(0.135)\end{array}$ & $\begin{array}{c}1.0-20.0 \\
3.17(3.08)\end{array}$ & $\begin{array}{c}18-109 \\
53.8(25.46)\end{array}$ \\
\hline & $\begin{array}{c}\mathrm{Cl}^{-} \\
\left(\mathrm{mg} \mathrm{L}^{-1}\right)\end{array}$ & $\begin{array}{l}\text { Conductivity } \\
\left(\mu \mathrm{S} \mathrm{cm}^{-1}\right)\end{array}$ & $\mathrm{pH}$ & $\begin{array}{c}\mathrm{TSS} \\
\left(\mathrm{mg} \mathrm{L}^{-1}\right)\end{array}$ & $\begin{array}{l}\mathrm{DO} \\
(\%)\end{array}$ & $\begin{array}{c}\text { Temperature } \\
\left({ }^{\circ} \mathrm{C}\right)\end{array}$ \\
\hline $\begin{array}{l}\text { Range for the } \\
\text { whole study area }\end{array}$ & $0.5-96$ & $33-924$ & $6.3-8.93$ & $0.3-242$ & $70-129$ & $1-23$ \\
\hline ADSH & $\begin{array}{c}1.9-15.9 \\
9.22(4.43)\end{array}$ & $\begin{array}{c}56-407 \\
163(62.9)\end{array}$ & $\begin{array}{c}6.8-7.8 \\
7.2(0.26)\end{array}$ & $\begin{array}{c}5-202 \\
11.3(20.8)\end{array}$ & $\begin{array}{l}90.5-121.5 \\
100(8.22)\end{array}$ & $\begin{array}{c}5.6-20.1 \\
15.5(5.49)\end{array}$ \\
\hline CTRO & $\begin{array}{l}1.15-17.17 \\
3.18(1.98)\end{array}$ & $\begin{array}{c}66-337 \\
177(63.4)\end{array}$ & $\begin{array}{c}6.5-7.9 \\
7.6(0.42)\end{array}$ & $\begin{array}{c}5.0-12.0 \\
5.3(1.38)\end{array}$ & $\begin{array}{c}86-121.5 \\
110(8.41)\end{array}$ & $\begin{array}{c}5.9-20.1 \\
14.9(3.11)\end{array}$ \\
\hline DGEM & $\begin{array}{c}0.67-28 \\
7.33(5.22)\end{array}$ & $\begin{array}{c}56-552 \\
229(129)\end{array}$ & $\begin{array}{c}6.5-8.9 \\
7.8(0.74)\end{array}$ & $\begin{array}{c}0.5-30 \\
4.5(5.79)\end{array}$ & $\begin{array}{c}91-129 \\
102(6.70)\end{array}$ & $\begin{array}{c}2-20.1 \\
14.1(4.43)\end{array}$ \\
\hline MCAH & $\begin{array}{c}12.7-21.5 \\
13.6(3.75)\end{array}$ & $\begin{array}{c}253-448 \\
274(83.3)\end{array}$ & $\begin{array}{c}7.3-7.9 \\
7.3(0.28)\end{array}$ & $\begin{array}{c}18-66 \\
23.6(20.5)\end{array}$ & $\begin{array}{c}94-96 \\
95(1.00)\end{array}$ & $\begin{array}{c}12.3-19.3 \\
13.0(3.03)\end{array}$ \\
\hline RUNI & $\begin{array}{c}6.1-90.8 \\
23.9(21.9)\end{array}$ & $\begin{array}{c}227-925 \\
416(169)\end{array}$ & $\begin{array}{c}7.3-8.5 \\
7.9(0.38)\end{array}$ & $\begin{array}{c}0.3-202 \\
29.2(55.8)\end{array}$ & $\begin{array}{c}70-113 \\
94(12.8)\end{array}$ & $\begin{array}{c}10.1-21.6 \\
14.4(2.53)\end{array}$ \\
\hline
\end{tabular}

$T K N$, total nitrogen; TP, total phosphorus; $B O D$, biochemical oxygen demand; $A D S H$, A. subhudsonis; $C T R O$, C. tropica; DGEM, D. geminata; $M C A H$, M. cahabaensis; RUNI, R. uniseriata; TSS, total suspended solids; DO, dissolved oxygen. 


\section{DISCUSSION}

Historical data concerning the first record of $D$. geminata in Italy date to 1880 (Brun, 1880). Indeed, the definition of $D$. geminata as a non-indigenous species for Italy should probably be reconsidered. Nevertheless, if we look at the distribution pattern of this species in Italy, the frequency of its records, its relative abundance and the formation of massive proliferations, we can confirm that the distribution range of $D$. geminata has recently been expanding. The records of $D$. geminata are undoubtedly limited to those basins included in the regional monitoring programs and to the implementation of the WFD. Despite this, the first records of macroscopic blooms of D. geminata in Piemonte date only to 2003 (personal observation, unpublished data) and they were never observed earlier.

Our results confirm that $D$. geminata is widespread throughout North-Western Italy. In the surveys conducted in Piemonte, Valle d'Aosta, and Liguria, D. geminata was detected in 123 samples out of 411 (ca. $30 \%$ of the samples collected from 2007 to 2010). Valle d'Aosta rivers seem to represent the most suitable habitat for $D$. geminata colonization for several reasons: the oligotrophic status of the waters, their good oxygenation, and the flow regulators (weirs and dams) in most hydrological networks of the region. During the three-year survey, D. geminata was detected in almost the entire Dora Baltea watercourse (160 $\mathrm{Km}$ ), from Dolonne (Aosta) to Strambino (Turin), with the exception of 3 sites in Valle d'Aosta and 1 in Piemonte immediately before its confluence with the Po river. Nevertheless, no macroscopic blooms were ever observed in Valle d'Aosta. It is possible that the high-speed flow typical of watercourses in this region does not favour the production of stalks and thus of blooms, which require more stable and constant conditions (Whitton et al., 2009).

From the comparison with literature data, the presence of D. geminata in Piemonte was confirmed at 4 sampling sites out of 12 (Ellero, Corsaglia, Vermegnana, and the upper part of the Tanaro river). D. geminata was detected all along the Tanaro and Bormida di Millesimo rivers during the 2007 surveys (Battegazzore et al., 2009), but its presence was not confirmed in 2010 (apart from the upper sampling station on the Tanaro, i.e. Priola, Cuneo).

Historical and literature data from Liguria are completely absent. The first results concerning diatom communities come from 2008. Up to 2010, D. geminata was found in 15 samples out of 80. Mann-Whitney test provided some general indications on the role of some chemical parameters (mainly nitrogen and mineral content) limiting the presence of D. geminata. Despite this, the role of other characteristics favouring its spread, such as river morphological alterations, diffusion pathways or closeness to already contaminated sites, cannot be neglected. The autecological data on D. geminata, based on the optimum calculations, confirmed the literature data. D. gem- inata shows a preference for cold and oligotrophic waters with low mineral content (Krammer and Lange-Bertalot, 1986; Patrick and Reimer, 1975; De Wolf, 1982; Potapova and Charles, 2007; Rabenhorst, 1853; Rawson, 1956; Sládeček, 1973). However, the ecological amplitude of the species seems to be wider than hypothesized in the old literature, confirming recent data (Battegazzore et al., 2009; Gunde-Cimerman et al., 2005; Kawecka and Sanecki, 2003; Kilroy et al., 2005; Sterrenburg et al., 2007).

Macroscopic blooms of $D$. geminata were limited to a few sites: they were never observed in Valle d'Aosta or Liguria, while they were present in several stretches in Piemonte. Literature data confirmed the presence of mats in the Po and Varaita rivers (Battegazzore et al., 2007) and high relative abundances were reported in the Corsaglia, Tanaro, Maira and Bormida rivers (Battegazzore et al., 2009). During our 2010 survey, macroscopic blooms covering the whole river bottom were observed only in the Germanasca and Pellice rivers. A weekly survey of these two sites confirmed the statements by several authors that $D$. geminata prefers a low-medium and stable discharge (mean value $\left.5.73 \mathrm{~m}^{3} \mathrm{~s}^{-1}\right)$ and a shallow streambed $(<0.35$ m) (Kirkwood et al., 2007; Miller et al., 2009). The artificial dam upstream of the sampling site on the Germanasca river probably favoured the establishment of these conditions, and the consequent massive proliferation (Kawecka and Sanecki, 2003; Kirkwood et al., 2007; Kirkwood et al., 2009; Skulberg, 1982; Spaulding, 2007; Whitton et al., 2009). The $\mathrm{pH}$ of these two rivers was generally neutral to slightly basic, in agreement with most references. River waters were well oxygenated, with DO values always above $90 \%$ and $10 \mathrm{mg} \mathrm{L}^{-1}$, and $\mathrm{SO}_{4}{ }^{2-}$ concentrations never below $5.2 \mathrm{mg} \mathrm{L}^{-1}$ (in agreement with information contained in Whitton et al., 2009). Nutrient concentrations were generally low, in agreement with average values found in the literature (Whitton et al., 2009). Riparian vegetation at these two stream sites was completely absent due to the bank and bank top modifications: the increase of ultraviolet radiation would probably favour the growth of $D$. geminata, as suggested by Sherbot and Bothwell (1993).

In accordance with several authors (Larned et al., 2007; Mundie and Crabtree, 1997; Whitton et al., 2009), we recorded a significant decrease of the EPT index followed by a huge increase of chironomids during blooms (Brown, 2008). In these conditions, the abundance of scrapers decreased, and thus D. geminata proliferation was not contrasted. Therefore, we tested whether mats could somehow limit the presence of taxa characterized by external respiratory mechanisms via tracheal gills, but no statistical evidence for this hypothesis was obtained. In disagreement with some publications (Whitton et al., 2009; Wyatt et al., 2008), we observed a decreased abundance of $A$. minutissimum during $D$. geminata blooms. 
However this disagreement could arise from different identification within the $A$. minutissimum group. In contrast, no significant variation of $A$. pyrenaicum was recorded. Stalked taxa, such as G. elegantissimum and $G$. tergestinum, seemed to be inhibited by massive $D$. geminata proliferations, probably due to spatial competition, whereas erect, motile and tube-dwelling forms were favoured and increased in abundance.

During our surveys, other taxa of ecological interest and with nuisance behaviour were recorded for the first time in North-Western Italy. A. subhudsonis was described in Africa in the early $19^{\text {th }}$ century (Hustedt, 1921). After this, it was recorded in Africa, Indonesia and South America, and since 1950 in the Antilles, Korea and Japan (Coste and Ector, 2000). According to Lange-Bertalot and Krammer (1989) and Coste and Ector (2000), the species was absent from Europe up to the 1990s. Indeed, starting from 1991 (Ector, 1991), A. subhudsonis was recorded in several European countries, such as Spain, Portugal, and France (Coste and Ector, 2000; Blanco et al., 2010; Novais, 2011). Our research confirmed the presence of this species in several NW Italian rivers, with high relative abundance in two of them. As confirmed by Blanco et al. (2010), A. subhudsonis can reach a relative abundance of over $20 \%$ of the whole community and in some cases can dominate the sample. From our data, the optimum for A. subhudsonis is reached at low $\mathrm{N}-\mathrm{NH}_{4}^{+}$, total phosphorus and BOD values but at relatively high $\mathrm{N}-\mathrm{NO}_{3}{ }^{-}$concentrations. These results are slightly different from the data obtained for the Duero Basin in Spain, where the species was recorded with higher nutrient optima and organic load concentrations.

C. tropica was recorded for the first time in Brazil (Metzeltin and Lange-Bertalot, 1998) and wrongly identified as Cymbella turgidula. In 2002, Krammer defined the length/width ratio and the presence of one single stigma in C. tropica as the diagnostic character to distinguish it from C. turgidula. Starting from this publication, C. tropica seemed to be distributed mainly in tropical areas, i.e. Brazil, Venezuela, Costa Rica, and Ecuador. Recent publications reported C. tropica in Guadeloupe (Lefrançois et al., 2010), Martinique (Desrosiers and Bargier, 2010), Central-Western Brazil (Da Silva, 2009), and New Jersey (Charles et al., 2010). In recent years, $C$. tropica was recorded in France (Coste et al., 2008) and Portugal (as C. cf tropica; Novais, 2011), but had never been detected in Italy before our study. Data on its ecology are poor. From our results, its range of tolerance for nutrients seems to be quite wide, but its optimum values are generally low, denoting a sensitive species with only adequate ecological reliability.

R. uniseriata was described by Sala et al. (1993) in South America but its diffusion has likely been underestimated, as it has probably been misclassified as Reimeria sinuata (Gregory) Kociolek and Stoermer. R. uniseriata differs from $R$. sinuata by the uniseriate striae, C-shaped foramina and the apical pore field at each pole (Sala et al., 1993). In Europe, this species has been recorded in Southern France (Coste and Ector, 2000), in the Danube river catchment (Ács et al. 2004, 2006) and in Portugal (Novais, 2011). A recent revision of the herbarium materials from Poland confirmed the presence and misidentification of the taxon in Polish waters starting from the early 1960s (Wilk-Woźniak and Wojtal, 2005), and thus it is probably no longer invasive according to our criteria. In Italy, it was recorded in the Dolomiti Bellunesi National Park (Cantonati and Spitale, 2009), and in two rivers of Central Italy, and one of Southern Italy (Torrisi and Dell'Uomo, 2009). The only published data regarding its presence in Piemonte concern the upper part of the Po basin (Battegazzore et al., 2007, 2009, 2010; Battegazzore, 2008, 2012). Our results suggest that $R$. uniseriata is the most tolerant species in terms of nutrient concentration, mineral content and organic loading. It is widespread in both Piemonte and Liguria, with no geological and biogeographical preferences.

M. cahabaensis was recorded in 46 samples collected from 1997 to 2004 in southern US rivers (Morales and Manoylov, 2009). Up to 2010, there were no published records of this species for Europe (and Italy). Our results and literature data (Morales and Manoylov, 2009) indicate that $M$. cahabaensis tolerates intermediate values of nutrients and organic loading and can be considered a good indicator of meso-eutrophic conditions. The distribution range of this species has been expanding lately. Recent surveys in both Piemonte and Lombardia highlighted the presence of this species in several rivers (Falasco, personal observations from samples collected in 2011). These records of the species were particularly important due to the high relative abundance of M. cahabaensis in the samples. In some cases, particularly in the Mincio and Oglio rivers but also in the Tanaro, the species reached up to $50 \%$ relative abundance, with substantial effects on the biodiversity of the community, which strongly decreased. The small size of the species and the scarce literature data on this taxon do not favour its correct identification. Thus, we provide LM and SEM pictures of recently collected populations in order to supply further iconographical material on this species (Fig. 3). M. cahabaensis is morphologically very close to Eolimna comperei Ector et al., and only scanning electron analyses can distinguish between them. The differences are related to the position of the hymens covering each areola, and the proximal and terminal end deflections of the raphe (Morales and Manoylov, 2009). These fine differences could have led to the misidentification of the two taxa during monitoring surveys. Indeed, E. comperei has frequently been recorded in Europe, in particular in France (Coste and Ector, 2000; Guillard and Ector, 2005), in the Duero basin (Blanco et 
al., 2010) and in Portugal (Novais, 2011). Thus far, there have been no records of this species for Italy. From a comparison with the literature data (especially Blanco et al., 2010 ), we can say that $E$. comperei tolerates intermediate values of nutrients and organic loading and can be considered a good indicator of mesotrophic conditions. The similar ecological preferences and morphological features, and the same nuisance behaviour suggest that more systematic investigations on the $E$. comperei type material and European samples are required in order to clarify its taxonomic position with respect to $M$. cahabaensis and their potential synonymy.

\section{CONCLUSIONS}

The results of this study provide detailed knowledge of the diatom flora in NW Italy, with some interesting implications for river management, and questions for future investigations.

Although D. geminata is not considered non-indigenous, its geographical range has expanded in recent years, with a preference for oligotrophic waters and regulated rivers. A tendency to produce blooms at sites depleted of riparian vegetation was observed in this study. Indeed, D. geminata is extremely resistant to drought conditions and is able to tolerate high UV radiation. River habitat modifications lead to a loss of ecosystem integrity, with effects on biodiversity and the spread of nuisance taxa such as D. geminata. Further research should be aimed at clarifying (also in quantitative terms) the relationship between $D$. geminata and human-induced physical modifications.

This is the first study recording the presence of $A$. subhudsonis, C. tropica, and M. cahabaensis in northern Italian rivers. These taxa must be considered non-indigenous in Italy with an increasing spread. Considering their relative abundance in the diatom community, their correct identification is essential to control their diffusion and their potential detrimental effects on the diatom community, as well as for a correct river classification following the WFD. Indeed the presence of these taxa is often associated with a decrease in species richness and biodiversity.

A focus on $R$. uniseriata, even though it is not considered bloom forming or non-indigenous, can shed further light on its identification and distribution, as this taxon has been misclassified as $R$. sinuata in some diatom floras.

\section{ACKNOWLEDGMENTS}

This study arises from a research collaboration between the University of Torino, and ARPA Valle d'Aosta and ARPA Liguria.

The authors are particularly grateful to Livia Mobili, Anna Risso and Rosella Bertolottofor providing data and samples, Luca Cardillo and Elena Piano for help with the field work. The authors thank the Water Resources Department of the Piemonte Region for providing us with the water quality data. The authors would like to thank CRP "G. Lippmann" and in particular Luc Ector and Maria Helena Novais for taking SEM pictures of Mayamaea cahabaensis, as well as Saul Blanco and Eduardo Morales for their systematic expertise on this species. The authors also thank Peter Christie for the linguistic revision.

This research was partly funded by Fondazione Goria and Banca CRT within the framework of "Master dei Talenti della Società Civile" and by ARPA Liguria.

\section{REFERENCES}

Ács É, Szabó K, Tóth B, Kiss KT, 2004. Investigation of benthic algal communities, especially diatoms of some Hungarian streams in connection with reference conditions of the Water Framework Directives. Acta Bot. Hung. 46:255-277.

Ács É, Szabó K, Kiss ÁK, Tóth B, Záray G, Kiss KT, 2006. Investigation of epilithic algae on the river Danube from Germany to Hungary and the effect of a very dry year on the algae of the river Danube. Arch. Hydrobiol. Suppl. Large rivers 16:389-417.

Battegazzore M, 2008. Distribution of Didymosphenia geminata in SW Piemonte (Italy): invasion or just lack of reference data?, p. 24. In: M. Cantonati, A. Scalfi and E. Bertuzzi (eds.), Central European Diatom Meeting (Abstract Book). Museo Tridentino di Scienze Naturali, Trento, Italy.

Battegazzore M, 2012. Environmental conditions of alpine springs of the upper Po river (NW Italy) on the basis of their epilithic diatom communities. Atti Soc. It. Sci. Nat. Museo Civ. Stor. Nat. Milano 153:49-62.

Battegazzore M, Gastaldi E, Giordano L, Mattone I, Morisi A, 2010. Importanza degli ambienti acquatici minori nella biodiversità di un'area protetta: il caso delle diatomee bentoniche del Parco Fluviale Gesso e Stura. Atti XX Congr. Naz. Soc. It. Ecologia, Roma, Italy. Poster session: p.164.

Battegazzore M, Lucadamo L, Gallo L, 2009. Diatoms in the SW Piemonte (N-Italy) biological river monitoring network, with particular attention to the possible expansion of distribution of the "invasive" species Didymosphenia geminata (Lyngbye) Schmidt in Italy. Studi Trent. Sci. Nat. 86:119-126.

Battegazzore M, Mogna M, Gaggino A, Morisi A, 2007. La diatomea Didymosphenia geminata (Lyngbye) Schmidt nel F. Po e nel T. Varaita. Invasione preoccupante causata da disturbo antropico o mancanza di conoscenza? Ann. Sci. Mass. Monv. 3:87-107.

Beeson DR, Mitchum K, 2006. The past and present status of Didymosphenia geminata in the upper East Boulder river, p. 24. In: S. Spaulding, R. Wiltshire and L. Elwell (eds.), Current knowledge of Didymosphenia geminata: developing a research and management response. Federation of Fly Fishers and EPA Region 8 held in association with Western Division American Fisheries Society Annual Meeting, Montana State University, MT, USA.

Beltrami ME, Blanco S, Ciutti F, Cappelletti C, Monauni C, Pozzi S, Rimet F, Ector L, 2008a. Distribution and ecology of Didymosphenia geminata (Lyngbye) M. Schmidt (Bacil- 
lariophyta) in Trentino watercourses (northern Italy). Cryptog. Algol. 29:141-160.

Beltrami ME, Cappelletti C, Ciutti F, 2008b. Didymosphenia geminata (Lyngbye) M. Schmidt (Bacillariophyta) in the Danube basin: new data from the Drava river (northern Italy). Plant Biosyst. 142:126-129.

Beltrami ME, Cappelletti C, Ciutti F, Hoffmann L, Ector L, 2008c. The diatom Didymosphenia geminata: distribution and mass occurrence in the Province of Trento (Northern Italy). Verh. Int. Vereinigung Limnol. 30:593-597.

Berthon V, Bouchez A, Rimet F, 2011. Using diatom life-forms and ecological guilds to assess organic pollution and trophic level in rivers: a case study of rivers in south-eastern France. Hydrobiologia 673:259-271.

Birks HJB, Line JM, Juggins S, Stevenson AC, ter Braak CJF, 1990. Diatoms and $\mathrm{pH}$ reconstruction. Philos. T. Roy. Soc. B 327:263-278.

Blanco S, Cejudo-Figueiras C, Álvarez-Blanco I, Bécares E, Hoffmann L, Ector L, 2010. Atlas de las diatomeas de la cuenca del Duero. Área de Publicaciones. Universidad de León: 386 pp.

Blanco S, Ector L, 2009. Distribution, ecology and nuisance effects of the freshwater invasive diatom Didymosphenia geminata (Lyngbye) M. Schmidt: a literature review. Nova Hedwigia 88:347-422.

Bona F, Falasco E, Fenoglio S, Iorio L, Badino G, 2008. Response of macroinvertebrate and diatom communities to human-induced physical alteration in mountain streams. River Res. Appl. 24:1068-1081.

Bonardi E, 1888. Premières recherches sur les diatomées de Vall'intelvi. J. Microgr. 12:303-382.

Boubée J, Jellyman D, Sinclair C, 2008. Eel protection measures within the Manapouri hydro-electric power scheme, South Island, New Zealand. Hydrobiologia 609:71-82.

Brown CA, 2008. Changes in the composition and growth of invertebrates in rocky mountain streams due to blooms of the nuisance diatom Didymosphenia geminata. In: Abstracts NABS 56th Ann. Meet., Salt lake City, UT.

Brun J, 1880. Diatomées des Alpes et du Jura et de la région suisse et française des environs de Genève. Masson, Genève and Paris.

Cantonati, M, Spitale D, 2009. The role of environmental variables in structuring epiphytic and epilithic diatom assemblages in springs and streams of the Dolomiti Bellunesi National Park (south-eastern Alps). Fundam. Appl. Limnol. Arch. Hydrobiol. 174:117-133.

Charles DF, Tuccillo AP, Belton TJ, 2010. Diatoms and the biological condition gradient in New Jersey rivers and streams: a basis for developing nutrient guidance levels. PCER Report, 10-03, 129 pp.

Cook EJ, Ashton G, Campbell M, Coutts A, Gollasch S, Hewitt C, Liu H, Minchin D, Ruiz G, Shucksmith R, 2008. Nonnative aquaculture species releases: implications for aquatic ecosystems, p. 155-184. In: M. Holmer, K. Black, C.M. Duarte, N. Marbà and I. Karakassis (eds.), Aquaculture in the Ecosystem. Springer, Heidelberg.

Corti B, 1893. Sul deposito villafranchiano di Castelnovate presso Somma Lombardo. Rend. R. Ist. Lombardo Sci. Lett. 26:1-26.

Coste M, Ector L, 2000. Diatomées invasives exotiques ou rares en France: principales observations effectuées au cours des dernières décennies. Syst. Geogr. P1. 73:373-400.

Coste M, Bountry S, Tison-Rosebery J, And Delmas F, 2008. Improvements of the Biological Diatom Index (BDI): Description and efficiency of the new version (BDI-2006). Ecol. Indic. 9:621-650.

Da Silva WJ, 2009. Cymbellales (Bacillariophyceae) perífiticas da bacia do Rio Descoberto, Distrito Federal (Goiás). PhD thesis, Universidade de Brásilia: 183 pp.

De Toni GB, Levi D, 1886. Primi materiali per il censimento delle diatomacee italiane (Parte II). Notarisia 4:1-19.

De Wolf H, 1982. Method of coding of ecological data from diatoms for computer utilization. Meded. Rijks Geol. Dienst 36:95-110.

Desrosiers C, Bargier N, 2010. DCE: Réseau de référence des cours d'eau de la Martinique - Année 2009. Rapport Final ASCONIT: $137 \mathrm{pp}$.

Ector L, 1991. Étude des populations de diatomeés benthiques du fleuve Miño et de ses affluents (NW de l'Espagne). Evaluation de la qualité de l'eau au moyen de 6 indices diatomiques. In: Agence de l'Eau Artois-Picardie (ed.), Actes du 11ème Colloque des Diatomistes de Langue Française, Douai, France.

Falasco E, Bona F, Badino G, Torrisi M, Blanco S, Ector L, 2008b. Autoecologia e distribuzione di alcune specie di diatomee invasive, p. 170. In: Atti XVII Convegno Gruppo per l'ecologia di base "G. Gadio", Alessandria, Italy.

Falasco E, Bona F, Mobili L, Hoffmann L, Ector L, 2008a. Characterization of diatom assemblages in alpine streams of North-West Italy, p. 132. In: Proc. 20th Int Diatom Symp., Dubrovnik, Croatia.

Finlay BJ, Monaghan EB, Maberly SC, 2002. Hypothesis: the rate and scale of dispersal of freshwater diatom species is a function of their global abundance. Protist 153:261-273.

Forni B, 1925. Contributo alla Ficologia del Verbano. Atti Ist. Bot. Univ. Pavia Ser. 3:361-376.

Forti A, 1900. Contribuzioni diatomologiche (VI). Diatomee bentoniche dei laghi intermorenici del canavese. Atti Reale Ist. Veneto Sci. Lett. Arti 40:775-793.

Ghetti PF, 1997. Manuale di applicazione Indice Biotico Esteso (I.B.E.). Provincia Autonoma di Trento, Trento: 222 pp.

Giaj-Levra P, 1927. Le diatomee del Piemonte. Nuovo Giorn. Bot. Ital. 34:886-957.

Giaj-Levra P, Abate O, 1994. Le diatomee d'acqua dolce in Italia. ENEA Serie Studi Ambientali, Roma: 290 pp.

Griffith JW, Henfrey A, 1883. The micrographic dictionary; a guide to the examination and investigation of the structure and nature of microscopic objects. John Van Voorst, London.

Guillard D, Ector L, 2005. Diatomées des cours d'eau des Pays de la Loire (France) et suivi annuel de la qualité biologique de 1999 à 2004. In: Livre des résumés et programme 24ème Colloque de l'Association des Diatomistes de Langue Française. 6-8 Sept. 2005, Bordeaux, France.

Gunde-Cimerman N, Oren A, Plemenitas A, 2005. Adaptation to life at high salt concentrations in Archaea, Bacteria, and Eukarya. Kluwer Academic Publishers, Dordrecht: 577 pp.

Hofmann G, Werum M, Lange-Bertalot H, 2011. Diatomeen im Süßwasser-Benthos von Mitteleuropa. Koeltz Scientific Books, Königstein: 908 pp.

Hustedt F, 1921. VI. Bacillariales. In: B. Schröder (ed.), Zell- 
pflanzen Ostafrikas, gesammelt auf der Akademischen Studienfahrt 1910. Hedwigia 63:117-173.

IRSA, 1994. Metodi analitici per le acque. Quaderni,100. Istituto Poligrafico e Zecca dello Stato, Roma: 342 pp.

Jónsson GS, Jónsson IR, Björnsson M, Einarsson SM, 2000. Using regionalization in mapping the distribution of the diatom species Didymosphenia geminata (Lyngb.) M. Schmidt in Icelandic rivers. Verh. Int. Vereinigung Theor. Limnol. 27:340-343.

Jónsson IR, Jónsson GS, Olafsson JS, Einarsson SM, Antonsson T, 2008. Occurrence and colonization pattern of Didymosphenia geminata in Icelandic streams. In: M.L. Bothwell, S. A. Spaulding (eds.), Proceedings of the 2007 International Workshop on Didymosphenia geminata. Can. Techn. Rep. Fish. Aquat. Sci. 2795:41-44.

Kara H, Şahin B, 2001. Epipelic and epilithic algae of Dexirmendere river (Trabzon, Turkey). Turk. J. Bot. 25:177-186.

Kawecka B, Sanecki J, 2003. Didymosphenia geminata in running waters of southern Poland - symptoms of change in water quality? Hydrobiologia 495:193-201.

Kilroy C, Snelder T, Sykes J, 2005. Likely environments in which the nonindigenous freshwater diatom, Didymosphenia geminata, can survive, in New Zealand. National Institute of Water and Atmospheric Research Ltd, Christchurch: 36 pp.

Kilroy C, Biggs BJF, Vyverman W, 2007. Rules for macro-organisms applied to microorganisms: patterns of endemism in benthic freshwater diatoms. Oikos 116:550-564.

Kirkwood AE, Shea T, Jackson LJ, McCauley E, 2007. Didymosphenia geminata in two Alberta headwater rivers: an emerging invasive species that challenges conventional views on algal bloom development. Can. J. Fish. Aquat. Sci. 64:1703-1709.

Kirkwood AE, Jackson LJ, McCauley E, 2009. Are dams hotspots for Didymosphenia geminata blooms? Fresh. Biol. 54:1856-1863.

Krammer K, 1997a. Die cymbelloiden Diatomeen. Teil 1. Allgemeines und Encyonema Part. Bibl. Diatomol. 36:1-382.

Krammer K, 1997b. Die cymbelloiden Diatomeen. Teil 2. Encyonema part, Encyonopsis and Cymbellopsis. Bibl. Diatomol. 37:1-469.

Krammer K, 2000. The genus Pinnularia. In: H. Lange-Bertalot (ed.), Diatoms of Europe. 1. A.R.G. Gantner Verlag K.G., Rugell: 584 pp.

Krammer K, 2002. Cymbella. In: H. Lange-Bertalot (ed.), Diatoms of Europe. 3. A.R.G. Gantner Verlag K. G., Rugell: 584 pp.

Krammer K, 2003. Cymbopleura, Delicata, Navicymbula, Gomphocymbellopsis, Afrocymbella. In: H. Lange-Bertalot (ed.), Diatoms of Europe. 4. A.R.G. Gantner Verlag K.G., Rugell: 530 pp.

Krammer K, Lange-Bertalot H, 1986. Bacillariophyceae Teil: Naviculaceae. 1. In: H. Ettl, J. Gerloff, H. Heynig and D. Mollenhauer (eds.), Süsswasserflora von Mitteleuropa. 2. Fischer Verlag, Stuttgart: 876 pp.

Krammer K, Lange-Bertalot H, 1988. Bacillariophyceae Teil: Bacillariaceae, Epithemiaceae, Surirellaceae. 2. In: H. Ettl, J. Gerloff, H. Heynig and D. Mollenhauer (eds.), Süsswasserflora von Mitteleuropa. 2. Fischer Verlag, Stuttgart: $610 \mathrm{pp}$.

Krammer K, Lange-Bertalot H, 1991a. Bacillariophyceae Teil: Centrales, Fragilariaceae, Eunotiaceae. 3. In: H. Ettl, J. Ger- loff, H. Heynig and D. Mollenhauer (eds.), Süsswasserflora von Mitteleuropa. 2. Fischer Verlag, Stuttgart: 598 pp.

Krammer K, Lange-Bertalot H, 1991b. Bacillariophyceae Teil: Achnanthaceae. Kritische Erg.anzungen zu Navicula (Lineolatae) und Gomphonema. 4. In: H. Ettl, J. Gerloff, H. Heynig and D. Mollenhauer (eds.), Süsswasserflora von Mitteleuropa. 2. Fischer Verlag, Stuttgart: 437 pp.

Lange-Bertalot H, 2001. Navicula sensu stricto, 10 Genera separated from Navicula sensu lato, Frustulia. In: H. LangeBertalot (ed.), Diatoms of Europe. 2. A.R.G. Gantner Verlag K.G., Rugell: 526 pp.

Lange-Bertalot H, Metzeltin D, 1996. Indicators of Oligotrophy. In: H. Lange-Bertalot (ed.), Iconographia Diatomologica. 2. Koeltz, Koenigstein: 390 pp.

Larned S, Arscott D, Blair N, Jarvie B, Jellyman D, Lister K, Schallenberg M, Sutherland S, Vopel K, Wilcock B, 2007. Ecological studies of Didymosphenia geminata in New Zealand, 2006-2007. In: NIWA Client Report CHC2007070. NIWA Project MAF07507, Christchurch.

Lavoie I, Hamilton PB, Campeau S, Grenier M, Dillon PJ, 2008. Guide d'identification des diatomées des rivieres de l'Est du Canada (Spiral-bound). Presses de l'Université du Québec, Boisbriand: $241 \mathrm{pp}$.

Lefrançois E, Coat S, Lepoint G, Vachiéry N, Gros O, Monti D, 2010. Epilithic biofilm as a key factor for small-scale river fisheries on Caribbean islands. Fish. Managem. Ecol. 18:211-220.

Lindstrøm, EA, Skulberg O, 2007. Didymosphenia geminata (Lyngbye) M. Schmidt, an indigenous constituent of the algal flora in Norwegian watercourses. In: Proc. Int. Meet. American Society for Limnology \& Oceanography, Santa Fe, USA.

Lindstrøm, EA, Skulberg O, 2008. Didymosphenia geminata a native diatom species of Norwegian rivers coexisting with the Atlantic salmon. Can. Tech. Rep. Fish. Aquat. Sci. 2795:35-40.

Lyngbye HC, 1819. Tentamen Hydrophytologiae Danicae: Continens omnia Hydrophyta Cryptogama Daniae, Holsatiae, Faeroae, Islandiae, Groenlandiae hucusque cognita, Systematice Disposita, Descripta et iconibus illustrata, Adjectis Simul Speciebus Norvegicis. Hafniae, Copenhagen: 248 pp.

Mack RN, Simberloff D, Lonsdale WM, Evans H, Clout M, Bazzaz F, 2000. Biotic invasions: causes, epidemiology, global consequences, and control. Ecol. Appl. 10:689-710.

Mandl L, 1839. Traité pratique du microscope et de son emploi dans l'étude des corps organisés, suivi de recherches sur l'organisation des animaux infusoires par D.C.G. Ehrenberg. J.-B. Baillière, Paris: 486 pp.

Merritt RW, Cummins KW, 1996. Trophic relations of macroinvertebrates, p. 453-474. In: F.R. Hauer, G.A. Lamberti (eds.), Methods in Stream Ecology. Academic Press Inc., San Diego.

Metzeltin D, Lange-Bertalot H, 1998. Tropische Diatomeen in Südamerika I. In: H. Lange-Bertalot (ed.), Iconographia Diatomologica. 5. Koeltz, Koenigstein: 695 pp.

Miller MP, McKnight DM, Cullis JD, Greene A, Vietti K, Liptzin D, 2009. Factors controlling streambed coverage of Didymosphenia geminata in two regulated streams in the Colorado front Range. Hydrobiologia 630:207-218.

Monti R, 1904. Limnologische Untersuchungen über einige Italienische Alpenseen. Forschungsber. Biol. Stat. Plön 11:252-275. 
Morales EA, Manoylov KM, 2009. Mayamaea cahabaensis sp. nov. (Bacillariophyceae), a new freshwater diatom from streams in the United States. P. Acad. Nat. Sci. Philad. 158:49-59.

Mundie JH, Crabtree DG, 1997. Effects on sediments and biota of cleaning a salmonid spawning channel. Fisheries Manag. Ecol. 4:111-126.

Noga T, 2003. Dispersion of Didymosphaenia geminata in the flowing waters of southern Poland. New sites of species occurrence in the Orawska watershed and the Orawska Basin. Oceanol. Hydrobiol. Stud. 32:159-170.

Novais MH, 2011. Estudo das diatomáceas bênticas em sistemas lóticos de Portugal Continental. 2. PhD Thesis, Universidade de Évora: 50 pp.

Patrick R, Reimer CW, 1975. The diatoms of the United States, exclusive of Alaska and Hawaii - Entomoneidaceae, Cymbellaceae, Gomphonemaceae, Epithemaceae. 2/1. Monogr. Acad. Nat. Sci. Phila. 13:1-213.

Potapova M, Charles DF, 2007. Diatom metrics for monitoring eutrophication in rivers of the United States. Ecol. Indic. 7:48-70.

Pritchard A, 1842. A history of infusoria, living and fossil: arranged according to "Die Infusionthierchen" of C.G. Ehrenberg. Whittaker and Co., London.

Rabenhorst L, 1853. Die Süsswasser-Diatomaceen (Bacillarien) für Freunde der Mikroskopie. Edward Kummer, Leipzig: $72 \mathrm{pp}$.

Rawson DS, 1956. Algal indicators of trophic lake types. Limnol. Oceanogr. 1:18-25.

Reichardt E, 1999. Zur Revision der Gattung Gomphonema. Die Arten um G. affine/insigne, G. angustum/micropus, G. acuminatum sowie gomphonemoide Diatomeen aus dem Oberoligozän in Böhmen. In: H. Lange-Bertalot (ed.), Iconographia Diatomologica. 8. A.R.G. Gantner Verlag K. G., Rugell.

Rieberger K, 1991. The distribution of the diatom Gomphonema geminata in Vancouver Island streams, province of British Columbia. Ministry of Environment, Vancouver.

Sala SE, Guerrero JM, Ferrario ME, 1993. Redefinition of Reimeria sinuata (Gregory) Kociolek \& Stoermer and recognition of Reimeria uniseriata nov. sp. Diatom Res. 8:439-446.

Shearer J, Erickson J, 2006. Didymosphenia geminata and the Rapid Creek brown trout fishery, South Dakota. In: Abstracts of Region 8 Biomonitoring and Bioassessment Meeting, Utah State University, Logan.

Shelby EL, 2006. An assessment and analysis of benthic macroinvertebrate communities associated with the appearance of Didymosphenia geminata in the White river below Bull Shoals Dam. Arkansas Department of Environmental Quality, Little Rock: 17 pp.

Sherbot DMJ, Bothwell ML, 1993. Didymosphenia geminata (Gomphonemaceae): a review of the ecology of D. geminata and the physicochemical characteristics of endemic catchments on Vancouver Island. Report: NHRI Contribution 93005. National Hydrology Research Institute, Envi- ronment Canada, Saskatoon. NHRI Contribution No. 93005 .

Skulberg OM, 1982. Effects of stream regulation on algal vegetation, p. 107-124. In: A. Lillehammer and S.J. Saltveit (eds.), Regulated rivers. Columbia University Press, New York.

Sládeček V, 1973. System of water quality from the biological point of view. Ergeb. Limnol. 7:1-218.

Spaulding SA, 2007. Report on algae in streams in North America: diatoms are behaving badly. Instaar Noon Seminar, University of Colorado, Boulder.

Sterrenburg FAS, Gordon R, Tiffany MA, Nagy SS, 2007. Diatoms: living in a constructal environment, p. 141-172. In: J. Seckbach (ed.), Algae and cyanobacteria in extreme environments. Springer, New York.

Stohlgren T, Jarnevich C, Kumar S, 2007. Forest legacies, climate change, altered disturbance regimes, invasive species and water. Unasylva 229:44-49.

Subakov-simiæ G, Cvijan M, 2004. Didymosphenia geminata (Lyngb.) Schmidt (Bacillariophyta) from the Tisa river (Serbia) - its distribution and specific morphological and ecological characteristics. Arch. Hydrobiol. Suppl. 154; Algol. Stud. 114:53-66.

Telford RJ, Vandvik V, Birks HJB, 2006. Dispersal limitation matters for microbial morphospecies. Science 312:1015.

Torrisi MC, Dell'Uomo A, 2009. Diatomee bentoniche del corso superiore di alcuni fiumi centro-appenninici. Studi Trent. Sci. Nat. 84:139-151.

UNI, 2005. Qualità dell'acqua - Norma guida per il campionamento di routine ed il pretrattamento di diatomee bentoniche da fiumi, Norma EN 13946.

Vanormelingen, P, Verleyen E, Vyverman W, 2007. The diversity and distribution of diatoms: from cosmopolitanism to narrow endemism. Biodivers. Conserv. 17:393-405.

Vyverman W, Verleyen E, Sabbe K, Vanhoutte K, Sterken M, Hodgson DA, Mann DG, Juggins S, Van De Vijver B, Jones V, Flower R, Roberts D, Chepurnov VA, Kilroy C, Vanormelingen P, De Wever A, 2007. Historical processes constrain patterns in global diatom diversity. Ecology 88:1924-1931.

Werum M, Lange-Bertalot H, 2004. Diatoms in Springs from Central Europe and elsewhere under the influence of hydrogeology and anthropogenic impacts. In: H. Lange-Bertalot (ed.), Iconographia Diatomologica. 13. Koeltz, Koenigstein: $417 \mathrm{pp}$.

Whitton BA, Ellwood NTW, Kawecka B, 2009. Biology of the freshwater diatom Didymosphenia: a review. Hydrobiologia 630:1-37.

Wilk-Woźniak E, Wojtal A, 2005. Different aspects of algal studies - some remarks. Oceanol. Hydrobiol. St. 34:177-185.

Wyatt KH, Hauer FR, Pessoney GF, 2008. Benthic algal response to hyporheic surface water exchange in an alluvial river. Hydrobiologia 607:151-161.

Zorza R, Honsell G, 2008. Studio delle diatomee bentoniche del fiume Natisone (Italia Nord-Orientale). In: Atti Museo Friulano di Scienze Naturali 30:73-88. 